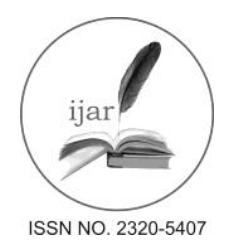

\author{
Journal homepage: http://www.journalijar.com

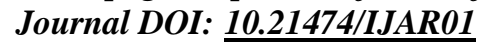

INTERNATIONAL JOURNAL

OF ADVANCED RESEARCH

RESEARCH ARTICLE

\title{
CENTRAL PUBLIC SECTOR UNDERTAKINGS (CPSUs) IN INDIA "WE ARE PROFITABLE AND SOCIAL"
}

\author{
*Mr. Samrat Ashok Jadhav ${ }^{1}$, Dr. Siddheshwar T. Gadade ${ }^{2}$. \\ 1. Research Scholar, C.K.Thakur College of Arts, Commerce and Science, New Panvel, Raigad, Affiliated to \\ University of Mumbai (MS), India. \\ 2. Ph. D. Guide, C.K.Thakur College of Arts, Commerce and Science, New Panvel, Raigad, Affiliated to \\ University of Mumbai (MS), India.
}

\section{Manuscript Info}

\section{Manuscript History:}

Received: 18 February 2016

Final Accepted: 19 March 2016

Published Online: April 2016

Key words:

Central Public Sector Undertakings and Social Contribution.

*Corresponding Author

Mr. Samrat Ashok Jadhav.

\section{Abstract}

In the era of competition and globalization the importance of privately owned business undertakings is rising. However, for a nation having mixed economy and developing economic status, excessively and completely relying on private players is risky. The individual contribution of private as well as public sector undertakings is significant. However, from last one and half decade unnecessary debates were going on proving the role of private sector and its efficiency. In fact, there is no significant association between the efficiency of work and the type of ownership.

To study the problem stated above, this work is intended to discover the contribution of Central Public Sector Undertakings in Indian economy, to analyse the aggregate profitability of Central Public Sector Undertakings, to explore the social contribution of Central Public Sector Undertakings and to provide useful suggestions and recommendations to Central Public Sector Undertakings. The authentic secondary sources of data, Public Enterprises Surveys and Annual Reports of Department of Public Enterprises are primarily used for the analytical purpose.

This study explored that the contribution of Central Public Sector Undertakings in Indian economy is significant; the aggregate profitability of Central Public Sector Undertakings is showing increasing trend and the social contribution of Central Public Sector Undertakings is above expected and statutory levels.

\section{Introduction:-}

In 1947, when the country becameindependent, there were various socio-economicproblems confronting the country, which needed to be dealt with in a plannedand systematic manner. India at that timewas an agrarian economy with a weakindustrial base, low level of savings, inadequate investment and lack ofinfrastructural facilities. There existedconsiderable inequalities in income andlevels of employment, glaring regionalimbalances in economic development andlack of trained manpower.

As such, State'sintervention in all the sectors of the economywas inevitable since private sector neitherhad the necessary resources, the managerialand scientific skill, nor the will to undertakerisks associated with large longgestationinvestments. Among the imperatives beforethe Government were the removal of poverty,equitable distribution of income, generationof employment opportunities, removal ofregional imbalances, accelerated growth ofagricultural and industrial production, better utilization of natural resources and a widerownership of economic power to prevent itsconcentration in a few hands. Given the typeand range of problems faced by the countryon the 
economic, social and strategic fronts, it became a pragmatic compulsion to use thepublic sector as an instrument for self-relianteconomic growth.

Central Public Sector Undertakings (CPSUs) have been set up to ensure the rapid economicdevelopment and industrialization ofthe country and to create thenecessaryinfrastructure for economicdevelopment;promote redistribution of income andwealth; create employment opportunities;promote balanced regionaldevelopment;assist the development of small-scaleand ancillary industries; promote import substitutions, and to earn foreign exchange for theeconomy. While there were only five Central PublicSector Undertakings (CPSUs) with a total investment of Rs.29 crore at the time of the First Five Year Plan. However,as on $31^{\text {st }}$ March, 2012, there were 260 CPSUs (excluding 7 Insurance Companies) with atotal investment of Rs.7, 29,228 crores.

A large number of CPSUs have been set up asGreenfield projects consequent to the initiatives taken duringthe Five Year Plans. CPSUs such as National TextileCorporation, Coal India Ltd. (and its subsidiaries) have,however, been taken over from the private sector consequentto their 'nationalization'. Whereas, industrial companies such asIndian Petrochemicals Corporation Ltd., Modern FoodIndustries Ltd., Hindustan Zinc Ltd., Bharat AluminumCompany and MarutiUdyog Ltd., whichwere CPSUs earlier, ceased to be CPSUs after their'privatization'.

Along with other public sector majors such as StateBank of India in the banking sector, Life InsuranceCorporation in the insurance sector and Indian Railways intransportation, the CPSUs are leading companies of Indiawith significant market-shares in sectors such as petroleum,(e.g. ONGC, GAIL and Indian Oil Corporation), mining (e.g.Coal India Ltd. and NMDC), power generation (e.g. NTPCand NHPC), power transmission (e.g. Power GridCorporation of India Ltd.), nuclear energy (e.g. NuclearPower Corporation of India Ltd.), heavy engineering (e.g.BHEL), aviation industry (e.g. Hindustan Aeronautics Ltd.and Air India Ltd.), storage and public distribution system(e.g. Food Corporation of India and Central WarehousingCorporation), shipping and trading (e.g. ShippingCorporation of India Ltd. and State Trading Corporation ofIndia Ltd.) and telecommunication (e.g. BSNL and MTNL).

With economic liberalization, post-1991, sectors thatwere exclusive preserve of the public sector enterprises wereopened to the private sector. The CPSUs therefore, arefaced with competition from both domestic fast growing private sectorcompanies and thelarge Multi-National Corporations (MNCs).

\section{Objectives of the study:-}

1. To study the contribution of CPSUs in Indian economy.

2. To analyse the aggregate profitability of CPSUs.

3. To explore the social contribution of CPSUs and

4. To provide useful suggestions and recommendations on CPSUs.

\section{Hypotheses of the study:-}

$\mathrm{H}_{1}$ : The contribution of CPSUs in Indian economy is significant.

$\mathrm{H}_{2}$ : There is an increase in the aggregate profitability of CPSUs.

$\mathrm{H}_{3}$ : The aggregate social contribution of CPSUs is more than the expected level social expenditure spending.

$\left(\mathrm{H}_{\mathrm{a}}>2 \%\right.$ of Net profit ).

\section{Research methodology:-}

This study is concentrating only on Central Public Sector Undertakings (CPSUs) in India. It is for the period of 10 years from 2002-03 to 2011-12. It is based on authentic secondary sources i.e. Public Enterprises Surveys and Annual Reports of Department of Public Enterprises (DPEs). The study is limited upto 2011-12 because the available data for the year2013-14 and 2014-15 is still provisional. This work is an analytical study. It is designed by adopting a macro level analytical approach. The data is analyzed by adopting required and suitable statistical tools and descriptive statistical techniques.

\section{Data analysis and interpretation:- CPSUs and Indian Economy:-}

The CPSUs have played a strategic role in the national economy and made significant contributions to the economy like building strong industrial and infrastructure base for India; major presence in vital sectors like petroleum, 
power, telecom, steel, aviation, coal, mining, engineering; monopoly in defense industries, atomic energy, railways; turnover (Rs.18, 41,927 crore during 2011-12); contribution to Exchequer (Rs.13,32,350 crores from 2002-03 to 2011-12); competition/cooperation with private sector; ensuring price stability of vital and sensitive products (like oil,gas, steel, coal, power, aluminium); Contribution of CPSUs to Gross Domestic Product (GDP) during the period 2002-03 to 2011-12 showed a decreasing trend, however it was always more than 6\% p.a.

Figure: 1. Contribution of CPSUs to Central Exchequer

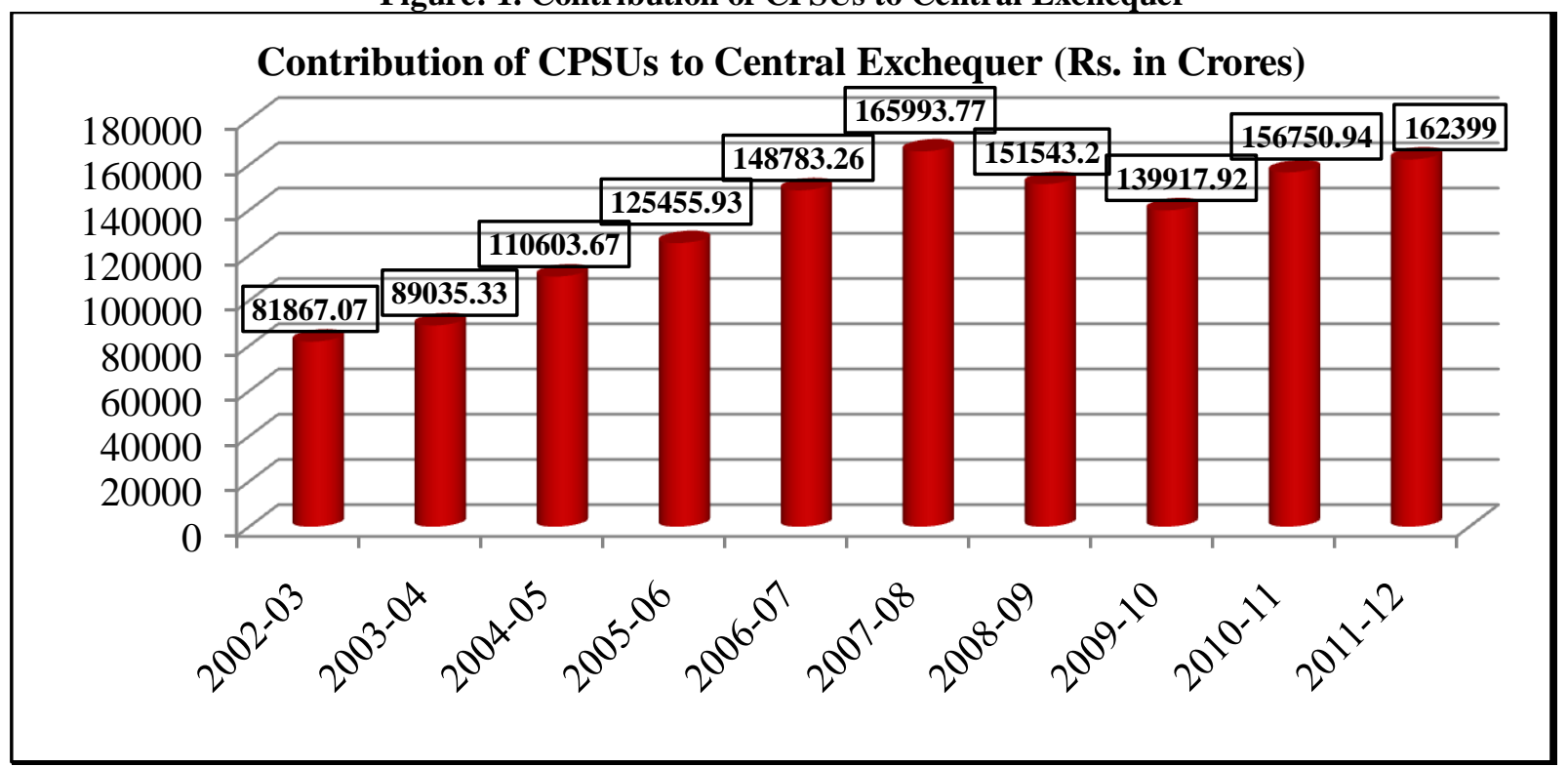

Source: Compiled by Researcher

Contribution of CPSUs to Central Exchequer during the period 2002-03 to 2011-12 was Rs.13, 32,350.09 crores. It showed an increase upto the year 2007-08. The contribution of CPSUs falls down consecutively for two years and again it started rising from 2010-11. In the year 2011-12 it was Rs.1,62,399 crores.

Mean Percentage of contribution of CPSUs in GDP of Indian Economy is 6\% p.a.

Thus, hypothesis: 1 - the contribution of CPSUs in Indian economy is significant is accepted.

\section{Aggregate Profitability of CPSUs:-}

The aggregate profitability of CPSUs is measured by deducting the loss of loss making CPSUs from the profits of profit making CPSUs and then the net profit is denoted as 'Aggregate Profit' of CPSUs. Thereafter, the 'Aggregate Profit' is distributed among the total operating CPSUs and 'Aggregate Profit Per CPSU' is calculated. By following this, the researcher found that all the operating CPSUs are in profit and the burden of loss of loss making enterprises is nullified. This approach is justifiable because these are the government undertakings whose aim is not only to secure profits but also to take care of welfare of people even by investing in the areas of expected loss.

Figure:2. shows that there is continuous rise in the aggregate profit per CPSU. It was Rs.143.12 crores in the year 2002-03 which increased to Rs.375.25crores in the year 2006-07. The rise in the aggregate profit per CPSU during this period of first 5 years is $162 \%$. From Rs.375.25 crores it has shown increase to Rs.436.65 crores in the year 2011-12. It means during the next five years' period it has shown an increase by $16 \%$ only. During the second half of the decade the aggregate profit per CPSU is increasing every year but at a decreasing rate. This is because of the increasing domination of private sector in the economy and the negligence of the owner to the significant status of their own undertakings. 
Figure: 2. Trend in Aggregate Profit Per CPSU

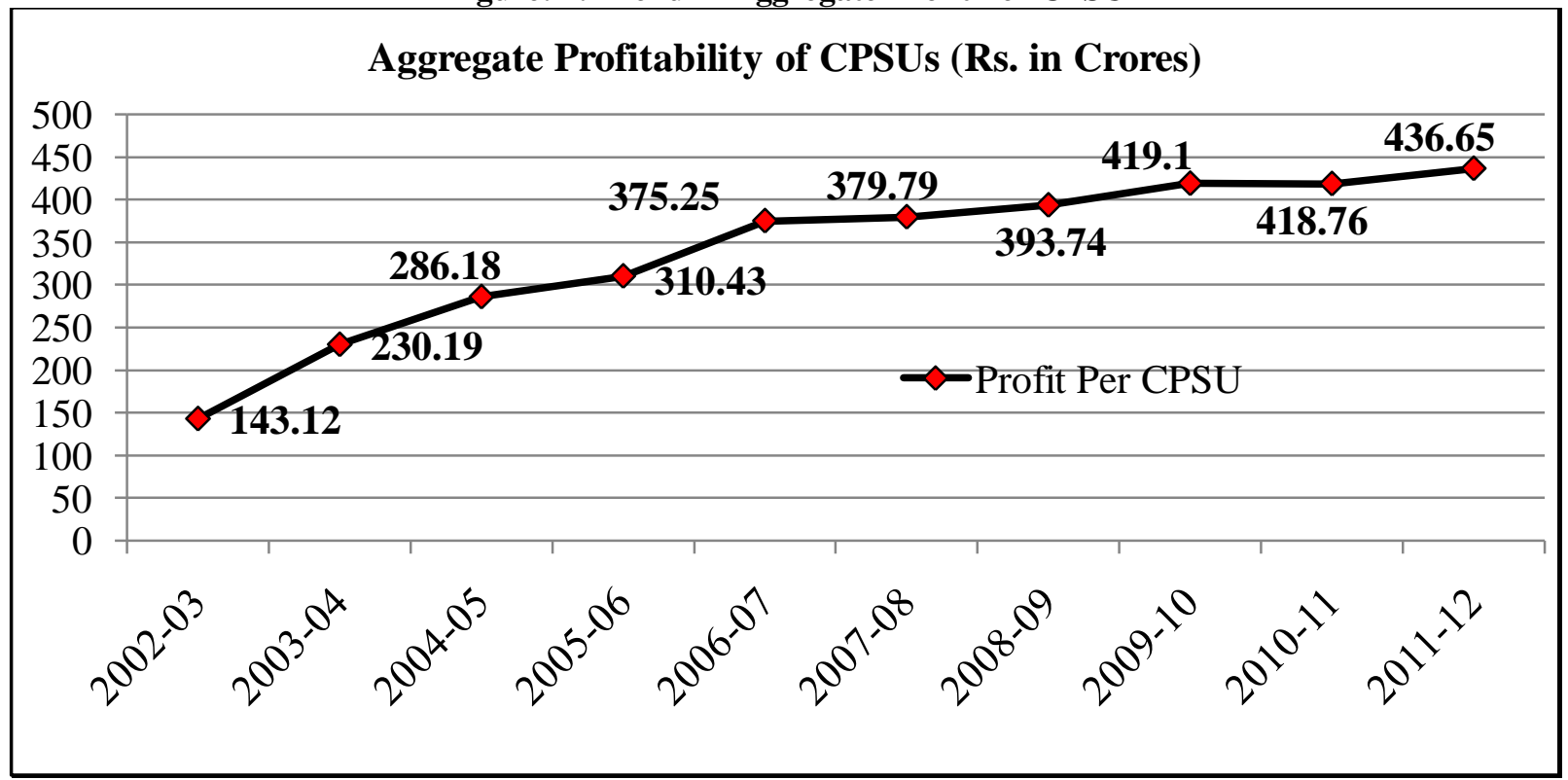

Source: Compiled by Researcher

Profit Per CPSU of Y-12 > Y-11, Y-10 > Y-09 > Y-08 > Y-07 > Y-06 > Y-05 > Y-04 > Y-03.

Thus, Hypothesis:2- there is an increase in the aggregate profitability of CPSUs is accepted.

Social Contribution of CPSUs in form of Social Expenditures:-

Over the years, most of the CPSUs have consciously and extensively promoted corporate social activities including providing employment to the weaker and under-privileged sections of the society on a more equitable basis; providing all inclusive social facilities to the employees and their families, especially in the areas of education, healthcare and entertainment; providing assistance to social and cultural activities beneficial to employees and associated sections of the community and participating in or contributing to the causes and activities dealing with natural disasters by protecting consumer interests and promoting India as business brand.

Table: 1. Social Expenditure to Net Profit Ratio

\begin{tabular}{|c|c|c|c|}
\hline \multicolumn{2}{|c|}{ Social Expenditures to Net Profit } & \multicolumn{2}{c|}{ Social Expenditure to Net Profit } \\
\hline Years & Percentage & Years & Percentage \\
\hline $2002-03$ & 6.77 & $2007-08$ & 3.87 \\
\hline $2003-04$ & 4.37 & $2008-09$ & 3.17 \\
\hline $2004-05$ & 3.68 & $2009-10$ & 3.33 \\
\hline $2005-06$ & 3.60 & $2010-11$ & 3.54 \\
\hline $2006-07$ & 4.00 & $2011-12$ & 3.07 \\
\hline
\end{tabular}

Source: Compiled by Researcher

The minimum percentage of social expenditure to net profit ratio during the period was 3.07 and maximum percentage was 6.77. The minimum percentage of Social Expenditures 3.07is more than the expected andmandatory social expenditure percentage on net profit. The expected and now mandatory percent of CSR expenditures is $2 \%$ of net profit.

$H_{a}>2 \%$ of Net Profit.

Thus, Hypothesis: 3 - the aggregate social contribution of CPSUs is more than the expected level social expenditure spending is accepted.

\section{Key findings and suggestions:-}

Though during the decade, the contribution of CPSUs in Indian GDP was never below 6\%p.a., it is showing a decreasing trend. The Government (The Real Owner) needs to focus on the strengthening of CPSUs strategically. 
Government should give the prime role to its own business undertakings. The increase in number of CPSUs in manufacturing business sector will be resulted into increase in the share of CPSUs in India's GDP.

The profitability per CPSUs is showing increment but at a decreasing rate. It can be converted to increasing rate with the suitable reforms in Human Resource Policies, Performance based Evaluation, creating competitiveness and more cost effectiveness. The major CPSUs like BPCL, HPCL, etc. from petroleum sector have shown us the path of reforms with efficiency. Suitable reforms in management and policy implementation is a necessity than going for disinvestment of public sector companies and giving scope for domination of private sector on this land of poor and economic middle class population.

Throughout the decade taken for the study, social contribution of CPSUs is considerable even before the mandatory spending on CSR. They contribute a lot in creating social infrastructure for their employees in particular and local community and others in general. However, the spending on CSR is showing reduction by 55\% in the year 2011-12 as compare to the CSR spending in the year 2002-03. It means in case of CPSUs mandatory recommendation resulted into reduction in spending on social transactions. The researcher recommends the exclusion of expenses towards employees' welfare and township from the bracket of CSR expenditure.

\section{Conclusion:-}

It is observed that with the Government support in terms of key enablers and reforms, the State-Owned Enterprises (SOEs) have played a pivotal role in building the economy of China. Based on the information provided by Ministry of Finance, Government of China, these enterprises recorded an average of 36\% of the country's GDP.For ensuring that the Indian economy continues to scale new heights and emerge as an economic superpower, it is imperative for the Central Public Sector Undertakings (CPSUs) to continue to demonstrate global competitiveness and achieve market leadership. As highlighted earlier, the empowerment of these enterprises by the Government has been a key enabler which has helped them in overcoming some of the operational constraints, critical for successful functioning of these organizations. However, to make these CPSUs emerge as global leaders in their respective areas, requisite reforms/ interventions need to be fast tracked. Concentration on CSPUs is inevitable to maintain the balance in mixed economy, India adopted.

\section{References:-}

1. DPE, (2003), Public Sector Enterprises Survey, Ministry of Heavy Industries and Public Enterprises, Government of India, India.

2. DPE, (2004), Public Sector Enterprises Survey, Ministry of Heavy Industries and Public Enterprises, Government of India, India.

3. DPE, (2005), Public Sector Enterprises Survey, Ministry of Heavy Industries and Public Enterprises, Government of India, India.

4. DPE, (2005), Public Sector Enterprises Survey, Ministry of Heavy Industries and Public Enterprises, Government of India, India.

5. DPE, (2007), Public Sector Enterprises Survey, Ministry of Heavy Industries and Public Enterprises, Government of India, India.

6. DPE, (2008), Public Sector Enterprises Survey, Ministry of Heavy Industries and Public Enterprises, Government of India, India.

7. DPE, (2009), Public Sector Enterprises Survey, Ministry of Heavy Industries and Public Enterprises, Government of India, India.

8. DPE, (2010), Public Sector Enterprises Survey, Ministry of Heavy Industries and Public Enterprises, Government of India, India.

9. DPE, (2011), Public Sector Enterprises Survey, Ministry of Heavy Industries and Public Enterprises, Government of India, India.

10. DPE, (2012), Public Sector Enterprises Survey, Ministry of Heavy Industries and Public Enterprises, Government of India, India.

11. DPE, (2012), Annual Report, Ministry of Heavy Industries and Public Enterprises, Government of India, India.

12. KPMG, (2015), CSR Reporting Survey, KPMG India, Dec., 2015, India. 